\title{
İnvaziv ve İnvaziv Olmayan Acinetobacter baumannii İzolatlarında Biyofilm Yapımı ve Virülans Genlerinin Varlıg̃ ı
}

\section{Biofilm Production and Presence of Virulence Genes in Invasive and Non-invasive Acinetobacter baumannii Isolates}

\author{
Öznur GÜRPINAR (IID), Alper ERGIN² (IDD), Pınar ZARAKOLU³ (IID), Özgen KÖSEOG̃LU ESER ${ }^{1}$ (ID)
}

\footnotetext{
${ }^{1}$ Hacettepe Üniversitesi Tıp Fakültesi, Tıbbi Mikrobiyoloji Anabilim Dalı, Ankara, Türkiye

${ }^{2}$ Hacettepe Üniversitesi Sag̃lık Hizmetleri Meslek Yüksekokulu, Ankara, Türkiye

${ }^{3}$ Hacettepe Üniversitesi Tıp Fakültesi, İnfeksiyon Hastalıkları ve Klinik Mikrobiyoloji Anabilim Dalı, Ankara, Türkiye
}

Makale atıfi: Gürpınar Ö, Ergin A, Zarakolu P, Köseoğlu Eser Ö. Invaziv ve invaziv olmayan Acinetobacter baumannii izolatlarında biyofilm yapımı ve virülans genlerinin varlığı. FLORA 2021;26(4):720-6.

\section{ÖZ}

Giriş: Acinetobacter baumannii'de antibiyotik direncinin gelişmesinde biyofilm yapımının yanı sıra birçok virülans geni de etkin role sahiptir. Bu çalışmada, infeksiyon tanısı almış hastalardan elde edilen çok ilaca dirençli A. baumannii izolatlarında biyofilm yapımı ve biyofilm yapımında rol oynadığı düşünülen virülans genlerinin (csuE ve ompA) varı̆ı̆ını araştırmak amaçlanmıştır.

Materyal ve Metod: Çalışma, Hacettepe Üniversitesi Hastanesinde yatan, invaziv/invaziv olmayan infeksiyon tanısı almış hastalardan elde edilen çok ilaca dirençli A. baumannii izolatlarında yapılmıştır. Tür tanımlaması konvansiyonel yöntemler ve MALDI-TOF MS ile yapılmıştır. Biyofilm yapımı, kantitatif mikroplak biyofilm yöntemi ile saptanmış ve virülans genleri olan csuE ve ompA varlığı polimeraz zincir reaksiyonu yöntemi kullanılarak tespit edilmiştir.

Bulgular: Çalışmaya dahil edilen toplam 100 izolat arasında yer alan invaziv A. baumannii klinik izolatları $(n=17)$; kateter $(n=6)$, kan $(n=$ 5), doku $(n=2)$, nefrostomi ile alınan idrar $(n=1)$, plevral sIVI $(n=1)$, eklem sIVIsI $(n=1)$ ve safra $(n=1)$ örneklerinden elde edilmiştir. Invaziv olmayan izolatlar ( $n=83)$; derin trakeal aspirat (\%53), püy (\%16), balgam (\%13) ve idrar (\%1) örneklerinden elde edilmiştir. İolatların 99'unda biyofilm varlığı gösterilmiştir. İzolatların 52'sinin güçlü, 31'inin orta ve 16'sının zayıf pozitif biyofilm üretimine sahip olduğu saptanmıştır. incelenen virülans genlerinden csuE, izolatların 88'inde [invaziv olmayan $(n=73)$, invaziv $(n=15)$ ], ompA geni ise 91 'inde [invaziv olmayan $(n=76)$, invaziv $(n=15)$ ] pozitif olarak tespit edilmiştir. Güçlü biyofilm yapımı gösteren 52 izolatın [invaziv olmayan ( $n=$ $40)$, invaziv $(n=12)$ ] 47'sinde, orta biyofilm yapımı gösteren 31 izolatın [invaziv olmayan $(n=26)$, invaziv $(n=5)$ ] 25 'inde csuE ve ompA virülans gen varlığı saptanmıştır.

Sonuç: Biyofilm yapımı, invaziv A. baumannii izolatlarında olduğu gibi invaziv olmayan izolatlarda da yüksek oranda tespit edilmiştir. Biyofilm yapımı görülen izolatlarda, biyofilm yapımı ile pili oluşum sisteminin bir parçası olan csuE geni ve ompA dış membran porin proteinini kodlayan ompA geni arasında yüksek oranda ilişki saptanmıştır. A. baumannii, çok ilaca dirençli invaziv olmayan izolatlarda da yüksek biyofilm yapımı ve virülans genlerinin varlığı ile nozokomiyal infeksiyonlarda tehdit oluşturmaya devam etmektedir.

Anahtar Kelimeler: Acinetobacter baumannii; Biyofilm; Virülans genleri 


\title{
ABSTRACT \\ Biofilm Production and Presence of Virulence Genes in Invasive and Non-invasive Acinetobacter baumannii Isolates
}

\author{
Öznur GÜRPINAR'1, AIper ERGIN², PInar ZARAKOLU³, Özgen KÖSEOG̃LU ESER ${ }^{1}$
}

\author{
${ }^{1}$ Department of Medical Microbiology, Hacettepe University Faculty of Medicine, Ankara, Turkey \\ ${ }^{2}$ Hacettepe University Vocational School of Health Services, Ankara, Turkey \\ ${ }^{3}$ Department of Infectious Diseases and Clinical Microbiology, Hacettepe University Faculty of Medicine, Ankara, Turkey
}

Introduction: Biofilm production and as well as many virulence genes play an active role in the development of antibiotic resistance in A. baumannii. In this study, it was aimed to investigate biofilm production in multidrug-resistant $A$. baumannii isolates obtained from patients diagnosed with infection and the presence of the virulence genes (csuE and ompA) thought to play a role in biofilm production.

Materials and Methods: This study was conducted on multi-drug resistant A. baumannii isolates obtained from patients hospitalized in Hacettepe University Hospital and diagnosed as having invasive/non-invasive infection. The identification of the species was carried out by conventional methods and MALDI-TOF MS. Biofilm production was determined by quantitative microplate biofilm method and the presence of the virulence genes csuE and ompA was determined using polymerase chain reaction method.

Results: Among the 100 isolates included in this study, invasive A. baumannii clinical isolates $(n=17)$ were determined from catheter $(n=6)$, blood $(n=5)$, tissue $(n=2)$, nephrostomy urine specimen $(n=1)$, pleural fluid $(n=1)$, joint fluid $(n=1)$ and bile $(n=1)$ samples. Non-invasive isolates $(n=83)$ were obtained from deep tracheal aspirate (53\%), pus (16\%), sputum (13\%) and urine (1\%) samples. The presence of biofilm was determined in 99 of the isolates. It was determined that 52 of the isolates had strong, 31 had medium and 16 had weak positive biofilm production. Of the virulence genes examined, csuE was positive in 88 [non-invasive $(n=73)$, invasive $(s=15)$ ] and the ompA gene was positive in 91 [non-invasive $(s=76)$, invasive $(s=15)$ ] of the isolates. The presence of csuE and ompA virulence genes were detected in 47 of 52 isolates [non-invasive $(n=40)$, invasive $(n=12)$ ] with strong biofilm production and in 25 of 31 isolates with medium biofilm production [non-invasive $(n=26)$, invasive $(n=5)$ ].

Conclusion: Biofilm production has been detected at a high rate in non-invasive isolates as well as in invasive A. baumannii isolates. In isolates with biofilm production, a high correlation was found between biofilm production and csuE gene which is a part of the pili formation system and ompA gene which encodes the ompA outer membrane porin protein. A. baumannii continues to pose a threat in nosocomial infections with high biofilm production and the presence of virulence genes in multidrug-resistant non-invasive isolates.

Key Words: Acinetobacter baumannii; Biofilm; Virulence genes

\section{GíRiș}

Acinetobacter baumannii, cok ilaca dirençli (MDR) hastane infeksiyonlarının en önemli etkenlerinden biridir. A. baumannii'ye bağlı infeksiyonların artısına ve etkenin artan klinik önemine rağmen patogenezinde rol oynayan faktörler hakkında az bilgi bulunmaktadır. A. baumannii hastane ortamında yașamını sürdürebilme potansiyeline sahiptir ve hastane ortaminda kullanılan esyalar ve tıbbi aletler üzerinde yașayabilmektedir. Bunlar arasında yer alan solunum cihazları ve kateterler, adezyon ve kolonize olma yeteneği nedeniyle, A. baumannii'ye bağlı ventilatör ilișkili pnömoni ve kan yolu infeksiyonlarının gelisiminde önemli bir role sahiptir ${ }^{[1]}$. Mikrobiyal biyofilm, mikroorganizmanın canlı veya cansız bir yüzeye yapıșması ve sonrasında bakterinin ürettiği hücre dıșı polisakkarit matriks içerisinde üremesi sonucu gelișen uzaklaștırılması zor mikroorganizma kümesidir. A. baumanniìnin tıbbi aletler üzerinde yasayabilmesi ve antibiyotiklere direncli olmasının bașlica nedeni, katı yüzeylerde biyofilm olușturabilme kabiliyetidir ${ }^{[2]}$.

Cok ilaca direncli $A$. baumannii infeksiyonlarının tedavisinde biyofilm yapımının engellenmesi ve virülans faktörlerinin inhibisyonuna yönelik geliștirilen peptitler, yeni terapötik stratejiler arasında önemli unsurlar olarak yer almaktadır. Biyofilm yapabilen $A$. baumannii izolatları konağın bağıșıklık mekanizmalarından kaçabilmekte, patojenin yașam süresinin uzamasına bağlı olarak klinik ortamlarda bulașıclığın uzamasına neden olmaktadır. A. baumanniïnin cansız yüzeylerde biyofilm olușturmasına neden olan bazı genetik yapilar bulunmaktadır. A. baumannii ATCC 19606 sușunda pilus yapımına yol açan csuA/BABCDE operonu, bakterinin yüze- 
ye tutunması ve biyofilm yapımı için gerekli olduğu ve klinik izolatlarda cok yaygın olarak bulunduğu gösterilmiștir. csuE geni $A$. baumannii nin biyofilm olușturmasında görev alan önemli yapilardan birisidir. csuE geninin inaktivasyonu ile pili olușumu ve biyofilm yapımı engellenmektedir. A. baumannii'nin konak hücreye tutunması, epitel hücre ölümü, erken apoptozis olușumu, dendritik hücrelerde gecikmiș nekroz olușumu ve dokulara invazyon gibi önemli role sahip olan ompA ise, $A$. baumannii'ye bağlı gelișen bakteriyemi ve nozokomiyal pnömonide mortaliteye etki eden en önemli virülans faktörüdür. Bu gen $A$. baumannii'nin biyofilm olușturmasını sağlamaktadır. Mutant $A$. baumannii izolatlarının biyofilm olușturamadığı, ompA allelinin yeniden eklenmesiyle biyofilm olușumunun tekrar bașladığı gösterilmiștir ${ }^{[3-5]}$.

$\mathrm{Bu}$ çalsșmada, invaziv ve invaziv olmayan infeksiyonu olan hastalardan elde edilen cok ilaca dirençli $A$. baumannii izolatlarında biyofilm yapımı ve biyofilm yapımında rol oynadığı düșünülen virülans genlerinin ( $c s u E$ ve ompA) varlığını araștırmak amaçlanmıștır.

\section{MATERYAL ve METOD}

\section{Hastalar ve Bakteri İzolatları}

Ocak-Aralı 2016 tarihleri arasında Hacettepe Üniversitesi Hastanesinde yatan hastalardan elde edilen, otomatize yöntemle (MALDITOF-MS, Bruker Daltonics, Almanya) A. baumannii olarak tanımlanan ve konvansiyonel yöntemlerle (Gram boyama, oksidaz, TSI besiyeri) doğrulanan izolatlar $(n=100)$ calıșmaya alınmıstır. Antibiyotik duyarlılık mikrodilüsyon yöntemiyle çalıșlmıș ve The European Committee on Antimicrobial Susceptibility Testing (EUCAST) kriterlerine göre değerlendirilmiștir $^{[6]}$. Amikasin, azitromisin, gentamisin, imipenem, meropenem, netilmisin, piperasilin, piperasilin+tazobaktam, sefepim, seftazidim, siprofloksasin, tigesiklin ve tobramisin duyarlllk sonucuna göre en az üc antibiyotik grubuna dirençli bulunan izolatlar cok ilaca dirençli olarak sınıflandırılmıștır ${ }^{[7]}$.

\section{Biyofilm Yapımının Kantitatif Mikroplak Yöntemi ile Belirlenmesi}

Biyofilm yapımının saptanması amaciyla kantitatif mikroplak biyofilm yöntemi uygulanmıștır ${ }^{[8]}$. A. baumannii izolatları $\% 0.25$ glikoz içeren triptik soy buyyon içinde steril mikroplak kuyucuklarda
18-24 saat $37^{\circ} \mathrm{C}$ 'de inkübe edilmistir. Serbest hücrelerin uzaklaștırılması amacıyla mikroplak kuyucukları üc kez steril fosfat tampon çözeltisi (PBS) ile yıkanmıștır. Metanol ile fiksasyon ișlemi sonrasında metanolün uzaklaștırılması amacıyla mikroplaklar oda sıcaklığında 15 dakika ters cevrilerek bekletilmiștir. Takiben kuyucuklar, \%1'lik kristal viyole ile oda sıcaklığında 20 dakika boyanmıștır. Mikroplakların yıkanmasının ardından kristal viyolenin çözünmesi için kuyucuklar \%95'lik etanolde 20 dakika bekletilmiștir. Mikroplaklar 15 dakika içinde 620 nm'de kantitatif sonucun doğrulanması amacıyla üc kez okutularak optik dansite (OD) belirlenmiștir. Çalıșmada, A. baumannii ATCC 19606 sușu pozitif kontrol olarak kullanılmıștır. Optik dansite sınır değeri (ODc), așağıdaki formülde gösterildiği gibi, negatif kontrolün OD değeri ortalamasının üzerinde üc standart sapma (SD) olarak belirlenmiștir: $\mathrm{ODc}=$ negatif kontrolün ortalama OD'si + (3 x SD negatif kontrol). Sonuçar optik dansitelerine göre; güçlü biyofilm oluşumu (4 x ODc <OD), orta düzeyde biyofilm oluşumu (2 x ODc $<\mathrm{OD} \leq 4 \times \mathrm{ODc})$; zayif biyofilm olușumu (ODc $<\mathrm{OD} \leq 2 \times \mathrm{ODc}$ ); ve biyofilm olmayan (OD $\leq \mathrm{ODc})$ olarak yorumlanmıstır.

\section{Virulans Genlerinin Polimeraz Zincir Reaksiyonu ile Belirlenmesi}

İzolatların DNA ekstraksiyonu sonrasında csuE (976 bp) ve ompA (966 bp) virülans genlerinin varlığı referans primerler kullanılarak polimeraz zincir reaksiyonu (PZR) yöntemi ile tespit edilmiștir ${ }^{[9,10]}$. PZR karıșımı $25 \mu$ l hacimde; Taq DNA tamponu, $2.5 \mathrm{mM} \mathrm{MgCl} 2,200 \mu \mathrm{M}$ dNTP karısım, 30 pmol (her biri) primer ve $1 \mathrm{U}$ Taq polimeraz $2 \mu$ DNA olacak sekilde hazırlanmıștır. DNA amplifikasyonu 1sı döngü cihazı (Global Genomics Partner, MyGenie96, ABD) ile gercekleștirilmiștir. İlk denatürasyon $94^{\circ} \mathrm{C}$ 'de 10 dakika gerçekleștirildikten sonra amplifikasyon; 35 döngü denatürasyon $94^{\circ} \mathrm{C}$ 'de 30 saniye, primer birlesmesi csuE için $63^{\circ} \mathrm{C}$ 'de ve ompA için $52^{\circ} \mathrm{C}$ 'de 30 saniye ve $72^{\circ} \mathrm{C}$ 'de 1 dakika olacak sekilde uygulanmıștır. Amplifikasyonun sonunda $72^{\circ} \mathrm{C}$ 'de 10 dakika son uzamanın ardindan reaksiyon sonlandırılmıștır. PZR ürünleri \%2'lik agaroz jel elektroforezinde yürütülmüștür. Moleküler ağırlık belirteci olarak 100 bp DNA ladder (Thermo Fisher Scientifics, Massachusetts, ABD) kullanılmıștır. 


\section{İstatistiksel Analiz}

İstatistiksel analizler IBM SPSS Statistics sürüm 23.0 yazılımı ile gerçeklestirilmiștir. Nitel verilerde tanımlayıcı istatistikler olarak sayı ve yüzde değerleri kullanılmıștır. Nitel değisskenler arasındaki ilișkileri incelemek için Pearson ki-kare ya da tabloda beklenen frekansı 5 'ten küçük göz olması durumunda Fisher'in kesin testi kullanılmıstır. P değeri 0.05 'ten kücuuk ise istatistiksel olarak anlamlı kabul edilmiștir.

\section{BULGULAR}

Bu calıșmaya, 62'si yoğun bakım, 38'i serviste yatan hastalardan infeksiyon etkeni olarak saptanan A. baumannii izolatları $(\mathrm{n}=100)$ dahil edilmiștir. İnvaziv $A$. baumannii klinik izolatları $(\mathrm{n}=17)$; kateter $(\mathrm{n}=6)$, kan $(\mathrm{n}=5)$, doku $(\mathrm{n}=2)$, nefrostomi ile alınan idrar $(\mathrm{n}=1)$, plevral sivı $(\mathrm{n}=1)$, eklem sivisı $(n=1)$ ve safra $(n=1)$ örneklerinden elde edilmiștir. İnvaziv olmayan izolatlar $(n=83)$; derin trakeal aspirat (\%53), püy (\%16), balgam (\%13), idrar (\%1) örneklerinden elde edilmistir.

İnvaziv izolatların $(n=17)$ yarısından fazlasının 12 antibiyotiğe dirençli olduğu saptanmıștır. İnvaziv olmayan izolatların $(s=83)$ yarısından fazlasinın 10 antibiyotiğge dirençli olduğu belirlenmiștir. İnvaziv ve invaziv olmayan izolatlarda farkl antibiyotiklere karșı dirençli izolat sayısı Tablo 1'de gösterilmiștir.

İnvaziv ve invaziv olmayan izolatlar arasında antibiyotik direnç açısından istatistiksel olarak
AZT, NET ve TOB'da anlaml farklllık bulunmus ( $p<0.05$ ) ve bu antibiyotiklere direnc invaziv izolatlarda istatistiksel olarak yüksek saptanmıștır.

İzolatların biyofilm yapımı açısından yapılan değerlendirmesinde, negatif kontrole göre yap1lan ölçümde izolatların 99'unda biyofilm olusumu kantitatif olarak gösterilmiștir. İzolatların 52'sinin gücliu pozitif, 31 'inin orta pozitif ve 16'sının zayıf pozitif biyofilm olușturduğu saptanmıștır.

İncelenen virülans genlerinden csuE, izolatların 88 'inde [invaziv olmayan, $s=73$ ve invaziv, $s=$ 15], ompA geni ise 91'inde [invaziv olmayan, $s=$ 76 ve invaziv, $s=15$ ] pozitif olarak tespit edilmistir. İnvaziv ve invaziv olmayan izolatlarda her iki gen açısından istatiksel fark Fischer kesin testine göre anlamlı olarak saptanmamıștır.

Güçlü biyofilm yapımı gösteren 52 izolatın [invaziv olmayan, $s=40$ ve invaziv $s=12$ ] 47 'sinde, orta biyofilm yapımı gösteren 31 izolatın [invaziv olmayan $s=26$, invaziv $s=5$ ] 25 'inde $c s u E$ ve ompA virülans gen varlığı saptanmıștır. Biyofilm derecesine göre; güçlü biyofilm yapımı olan invaziv olmayan izolatlarda csuE gen varlığı daha fazla iken, zayıf biyofilm yapımı olan invaziv olmayan izolatlarda ompA gen varlığı daha fazla saptanmıstır. Biyofilm derecesine göre invaziv ve invaziv olmayan izolatlarda her iki gen açısından Fischer kesin testine göre istatiksel fark anlamlı olarak saptanmamıștır. Biyofilm yapımı ile virülans genlerinin görülme sıklığı Tablo 2'de gösterilmiștir.

Tablo 1. İnvaziv ve invaziv olmayan izolatlarda 13 farklı antibiyotiğe karşı dirençli izolat sayısı

\begin{tabular}{lccccccccccccc} 
İzolatlar (100) & AN & AZT & GEN & IMP & MER & NET & PIP & PIP+TAZ & FEP & CAZ & CIP & TIG & TOB \\
\hline İnvaziv $(n=17)$ & 8 & 17 & 13 & 15 & 16 & 16 & 17 & 16 & 16 & 16 & 16 & 1 & 13 \\
İnvaziv Olmayan $(n=83)$ & 39 & 66 & 58 & 67 & 63 & 60 & 76 & 70 & 72 & 72 & 73 & 5 & 36
\end{tabular}

AN: Amikasin, AZT: Azitromisin, GEN: Gentamisin, IMP: İmipenem, MER: Meropenem, NET: Netilmisin, PIP: Piperasilin, TAZ: Tazobaktam, FEP: Sefepim, CAZ: Seftazidim, CIP: Siprofloksasin, TIG: Tigesiklin, TOB: Tobramisin.

Tablo 2. Biyofilm oluşumunun kantitatif dağılımı ile virülans gen ilişkisi

\begin{tabular}{|c|c|c|c|c|c|c|}
\hline \multirow{2}{*}{ Virülans genleri } & \multicolumn{2}{|c|}{$\begin{array}{l}\text { Güçlü Biyofilm Oluşumu } \\
(n=52)\end{array}$} & \multicolumn{2}{|c|}{$\begin{array}{l}\text { Orta Biyofilm Oluşumu } \\
\qquad(n=31)\end{array}$} & \multicolumn{2}{|c|}{$\begin{array}{l}\text { Zayıf Biyofilm Oluşumu } \\
\qquad(n=16)\end{array}$} \\
\hline & $\begin{array}{l}\text { İnvaziv } \\
(n=12)\end{array}$ & $\begin{array}{l}\text { İnvaziv olmayan } \\
\quad(n=40)\end{array}$ & $\begin{array}{c}\text { İnvaziv } \\
(n=5)\end{array}$ & $\begin{array}{l}\text { İnvaziv olmayan } \\
(n=26)\end{array}$ & $\begin{array}{l}\text { İnvaziv } \\
(n=1)\end{array}$ & $\begin{array}{l}\text { İnvaziv olmayan } \\
\qquad(n=15)\end{array}$ \\
\hline csuE & 11 & 39 & 3 & 25 & 1 & 8 \\
\hline ompA & 12 & 36 & 2 & 25 & 1 & 14 \\
\hline
\end{tabular}




\section{TARTIȘMA}

Cok ilaca dirençli $A$. baumannii izolatlarının hastane ortamında yașaması ve direnc kazanması, önemli bir nozokomiyal infeksiyon etkeni olmasını sağlamıștır. Bakterinin hastane ortamında infeksiyon etkeni olarak yüksek oranlarda ortaya çkması, en önemli virülans faktörlerinden biri olan biyofilm yapımına bağlıdır ${ }^{[5]}$. Dünya'da yapılan birçok çalıșmada $A$. baumannii izolatlarında yüksek seviyede biyofilm yapımı tespit edilmistir. Rosales-Reyes $\mathrm{R}$ ve arkadașlarl ${ }^{[11]}$ nozokomiyal infeksiyon etkeni olarak elde edilen $A$. baumannii izolatlarının \%96.4'ünde (108/112) biyofilm varlığı göstermiștir. Amin $M$ ve arkadașları ${ }^{[12]}$, invaziv ve invaziv olmayan toplam 64 A. baumannii izolatının 55 'inde biyofilm varlığını tespit etmiștir. Calıșmamızda, hastanede yatan hastalardan infeksiyon etkeni olarak elde edilen hem invaziv ve hem de invaziv olmayan A. baumannii izolatlarında biyofilm yapımının yüksek olduğu belirlenmiștir. Bu calıșma kapsamındaki 100 izolatın 99'unda kantitatif mikroplak tekniği ile biyofilm olușumu tespit edilmiștir.

Cok ilaca direncli $A$. baumannii izolatlarında yeni tedavi seçenekleri azalmaktadır. Bu çalıșma kapsamında yer alan invaziv ve invaziv olmayan izolatların her iki grupta yarısından fazlasının 10'dan fazla farklı antibiyotiğe dirençli olduğu saptanmıștır. Daha sıklıkla yoğun bakımda tedavi gören hastalardan elde edilen izolatlarda (\%62) ise, biyofilm yapımı ile birlikte iki virülans geninin varlığı yüksek düzeyde saptanmıștır. Yoğun bakım ünitesi gibi invaziv girișimlerin arttığı ortamlarda hastallk etkeni olan $A$. baumannii izolatlarının biyofilm üretimi ile birlikte yüksek antibiyotik direnci de gösterdiği görülmektedir. Biyofilm üretimini baskılamaları açısından günümüzde birçok peptid versiyonu üzerinde calıșmalar yapılmaktadır. Özellikle insan katelisidinlerinden LL-37'den geliștirilen peptit 148, sığır katelisidinlerinden indolisidin ve Afrika peçeli kurbağasından elde edilen magainin-2 peptitlerinin, cok ilaca direncli A. baumannii izolatlarının olușturduğu biyofilm yapısını durdurma, parçalama sonucu antibiyofilm etki gösterdiği ve etkene bağlı infeksiyonların tedavisinde umut olabileceği gösterilmiștir ${ }^{[13-15]}$.

Zeighami $\mathrm{H}$ ve arkadașlarının yoğun bakımda en az 48 saat kalmıs ve semptomatik klinik infeksiyonu olan hastalardan elde edilmis kan, balgam, yara, idrar örneklerinde üremis 100 adet $A$. baumannii ile yapmıs oldukları çalıșmada, izolatların \%91'inin yayğın ilaç dirençli olduğu, bütün izolatların örnek tipi fark etmeksizin biyofilm olușturduğu (güçlü= 58 , orta $=42$ ) ve bütün izolatların en azından bir biyofilm ile ilișkili gen içerdiği (csuE $=\% 100$, $\operatorname{omp} A=\% 81$ ) saptanmıstır ${ }^{[16]}$. Boone RL ve arkadașlarının $A$. baumannii izolatlarında virülans fenotiplerini irdeledikleri çalıșmasında kandan elde edilen $A$. baumannii izolatlarının, balgam, yara, vb. örneklerden elde edilen izolatlardan daha fazla biyofilm olușturdukları gösterilmiștir ${ }^{[17]}$.

Dünyada yapılan birçok çalıșmada, biyofilm yapımı ile bakteri virülansı arasında doğru bir ilișki olduğu gösterilmiștir. Bakterinin virülansında önemli rol oynayan bap, csuE, ompA, pgaA, abal gibi birçok genin varlığ1, $A$. baumanniỉnin biyofilm olușturma kapasitesini artırmaktadır. Virülans genlerinin bazıları biyofilm olușturmayan izolatlarda da gözlenmesine rağmen, söz konusu genlerin görülme sıklığ1 ve ekspresyonu biyofilm olusturan izolatlarda daha yüksek tespit edilmistir $^{[2,12]}$. Calıșmamızda csuE geni pili yapımı ve infeksiyon olușturma basamağında önemli bir role sahip olmas1, ompA geni ise bakterideki biyofilm yapımını arttırması ve ilac hedefi olması nedenleriyle seçilmiștir. Calıșmamızda izolatların biyofilm düzeylerine göre csuE ve ompA gen varliklar1nin invaziv ve invaziv olmayan izolatlarda sayisal açıdan cok farklllık göstermediği sadece invaziv olmayan zayıf pozitif biyofilm varlığı gösteren izolatlarda ompA gen varlığını csuEden belirgin olarak fazla olduğu izlenmiștir (Tablo 2). CCalıșma izolatlarında genel olarak ompA gen varlı̆ı̆ının daha yüksek oranda olduğu görülmüștür. Virülans genlerinin varlığı ile biyofilm yapımının ilișkisi incelendiği Shenkutie AM ve arkadașlarının calıșmasında ise, incelenen $A$. baumannii izolatlarının yaklașı \%50'sinde biyofilm üretimi gözlenmemis olmasına rağmen, bu izolatların hepsinde csuE, adeFGH, ompA ve abal gen varlıklarının olduğu saptanmıștır. Bu nedenle, biyofilm ile ilișkili bu genlerin biyofilm olușturan ve olușturmayan izolatlarda ekspresyon seviyelerinin karșlastırılması gerektiği belirtilmiștir ${ }^{[18]}$. OmpA, konak epiteline adezyon, hücre cekirdeğine translokasyon sonucu hücrede sitotoksik etki ile hücre ölümüne ve serum 
direncine neden olmaktadır ${ }^{[19-21]}$. OmpA'nın bu özelliği dıșında antimikrobiyal dirençle de iliskili olduğu düșünülmektedir. Çalıșmamızda yer alan cok ilaca direncli olan izolatlarda biyofilm yapımı ile birlikte ompA'nın yüksek düzeyde tespit edilmesi bu iliskiyi destekler niteliktedir. A. baumannii'de ompA'nın așırı yapımının özellikle nozokomiyal pnömoni ve bakteriyemilerde tek bassına bağımsız risk faktörü olduğu bilinmektedir ${ }^{[22]}$. OmpA ekspresyonunun kantitatif moleküler yöntemlerle hızlı tespiti, özellikle risk grubu yüksek hastalarda çok ilaca dirençli $A$. baumannii izolatlarının erken tanısı açısından kullanılmaya adaydır ${ }^{[23]}$. Calıșmamizda yer alan izolatlarda biyofilm yapımıyla ilgili diğer genlerin ve varlıklarını gösterdiğimiz csuE ve ompA genlerinin ekspresyon mekanizmalar1nın calıșlamamıs ve izolatlar arasındaki benzerlik analizinin yapılamamıș olması çalıșmadaki önemli kısıtllliklar olarak belirlenmiștir.

Sonuc olarak, biyofilm yapımı invaziv A. baumannii izolatlarında olduğu gibi invaziv olmayan izolatlarda da yüksek oranda tespit edilmiştir. Biyofilm yapımı görülen izolatlarda, biyofilm yapımı ile pili olușum sisteminin bir parçası olan csuE geni ve ompA dis membran porin proteinini kodlayan ompA geni arasında yüksek oranda ilișki saptanmıștır. A. baumannii, cok ilaca dirençli invaziv olmayan izolatlarda da yüksek biyofilm yapımı ve virülans gen ekspresyonu ile nozokomiyal infeksiyonlarda tehdit olușturmaya devam ederken özellikle ompA, A. baumannii infeksiyonlarında yeni bir terapötik hedef olarak calıșlmaya değer görünmektedir.

\section{TEŞEKKÜR}

Çalıșmanın istatistik analizleri için Prof. Dr. Erdem Karabulut'a teșekkür ederiz.

\section{ETIK KURUL ONAYI}

$\mathrm{Bu}$ calıșma, Hacettepe Üniversitesi Girișimsel Olmayan Klinik Araștırmalar Etik Kurulu tarafından değerlendirilmis, 22.09.2020 tarih ve 16969557-1310 sayılı karar ile araștırma alanının etik kurullar kapsamı dıșında kaldığı belirtilmiștir.

\section{ÇIKAR ÇATIŞMASI}

Yazarlar bu makale ile ilgili herhangi bir clkar catıșması bildirmemișlerdir.

\section{YAZAR KATKISI}

Anafikir/Planlama: ÖKE, ÖG

Analiz/Yorum: ÖKE, AE, ÖG

Veri sağlama: ÖKE, AE, ÖE, PZ

Yazım: AE, ÖE

Gözden Geçirme ve Düzeltme: ÖKE, AE, PZ Onaylama: ÖKE, AE, PZ, ÖG

\section{KAYNAKLAR}

1. Harding CM, Hennon SW, Feldman MF. Uncovering the mechanisms of Acinetobacter baumannii virulence. Nat Rev Microbiol 2018;16:91-102.

2. Wang YC, Huang TW, Yang YS, Kuo SC, Chen CT, Liu CP, et al. Biofilm formation is not associated with worse outcome in Acinetobacter baumannii bacteraemic pneumonia. Sci Rep 2018;8:7289.

3. Yang CH, Su PW, Moi SH, Chuang LY. Biofilm formation in Acinetobacter baumannii: Genotype-phenotype correlation. Molecules 2019;24:1849.

4. Nie D, Hu Y, Chen Z, Li M, Hou Z, Luo X, et al. Outer membrane protein $A(\mathrm{OmpA})$ as a potential therapeutic target for Acinetobacter baumannii infection. J Biomed Sci 2020;27:26.

5. Longo F, Vuotto C, Donelli G. Biofilm formation in Acinetobacter baumannii. New Microbiol 2014;37:119-27.

6. The European Committee on Antimicrobial Susceptibility Testing. Breakpoint tables for interpretation of MICs and zone diameters, version 9.0, 2019.

7. Magiorakos AP, Srinivasan A, Carey RB, Carmeli Y, Falagas ME, Giske CG, et al. Multidrug resistant, extensively drug-resistant and pandrug-resistant bacteria: an international expert proposal for interim standard definitions for acquired resistance. Clin Microbiol Infect 2012;18:268-81.

8. Bardbari AM, Arabestani MR, Karami M, Keramat F, Alikhani MY, Bagheri KP. Correlation between ability of biofilm formation with their responsible genes and MDR patterns in clinical and environmental Acinetobacter baumannii isolates. Microb Pathog 2017;108:122-8.

9. Turton JF, Gabriel SN, Valderrey C, Kaufmann ME, Pitt TL. Use of sequence-based typing and multiplex PCR to identify clonal lineages of outbreak strains of Acinetobacter baumannii. Clin Microbiol Infect 2007;13:807-15.

10. Rodríguez-Baño J, Martí S, Soto S, Fernández-Cuenca F, Cisneros JM, Pachón J, et al. Biofilm formation in Acinetobacter baumannii: associated features and clinical implications. Clin Microbiol Infect 2008;14:276-8.

11. Rosales-Reyes R, Gayosso-Vazquez C, Fernandez-Vazquez IL, Jarillo-Quijada MD, Rivera-Benítez C, Santos-Preciado JI, et al. Virulence profiles and innate immune responses against highly lethal, multidrug-resistant nosocomial isolates of Acinetobacter baumannii from a tertiary care hospital in Mexico. PLoS ONE 2017;12:e0182899. 
12. Amin $M$, Navidifar $T$, Shooshtari FS, Rashno $M$, Savari $M$, Jahangirmehr $F$, et al. Association between biofilm formation, structure, and the expression levels of genes related to biofilm formation and biofilm-specific resistance of Acinetobacter baumannii strains isolated from burn infection in Ahvaz, Iran. Infect Drug Resist 2019;12:3867-81.

13. de Breij A, Riool M, Cordfunke RA, Malanaovic $N$, de Boer L, Koning RI, et al. The antimicrobial peptide SAAP-148 combats drug-resistant bacteria and biofilms. Sci Trans/ Med 2018;10:eaan4044.

14. Wang G, Li X, Wang Z. APD3:the antimicrobial peptide database as tool for research and education. Nucleic Acids Res 2015;44:D1087-93.

15. Kim MK, Kang N, Ko SJ, Park J, Park E, Shin DW, et al. Antibacterial antibiofilm activity and mode of action of magainin 2 against drug-resistant Acinetobacter baumannii. Int J Mol Sci 2018;19:3041.

16. Zeighami H, Valadkhani F, Shapouri R, Samedi E, Haghi F. Virulence characteristics of multidrug resistant biofilm forming Acinetobacter baumannii isolated from intensive care unit patients. BMC Infect Dis 2019;19:629.

17. Boone RL, Whitehead B, Avery TM, Lu J, Francis JD, Guevara $M A$ et al. Analysis of virulence phenotypes and antibiotic resistance in clinical strains of Acinetobacter baumannii isolated in Nashville, Tennessee. BMC Microbiol 2021;21.

18. Shenkutie AM, Yao MZ, Siu GK, Wong BKC, Leung PH. Biofilm-induced antibiotic resistance in clinical Acinetobacter baumannii isolates. Antibiotics (Basel) 2020;9:817.

19. Sugawara $E$, Nikaido $H$. OmpA is the principal nonspecific slow porin of Acinetobacter baumannii. I Bacteriol 2012;194:4089-96.
20. Gaddy IA, Tomaras AP, Actis LA. The Acinetobacter baumannii 19606 OmpA protein plays a role in biofilm formation on abiotic surfaces and in the interaction of this pathogen with eukaryotic cells. Infect Immun 2009;77:3150-60.

21. Kim SW, Moon DC, Jin JS, Lee JH, Shin JH, Kim JM, et al. Serum resistance of Acinetobacter baumannii through the binding of factor $\mathrm{H}$ to outer membrane proteins. FEMS Microbiol Lett 2009;301:224-31.

22. Sanchez-Encinales $V$, Alvarez-Marin R, Pachon-Ibanez ME, Fernandez-Cuenca F, Pascual A, Garnacho-Montero J, et al. Overproduction of outer membrane protein a by Acinetobacter baumannii as a risk factor for nosocomial pneumonia, bacteremia, and mortality rate increase. J Infect Dis 2017;215:966-74.

23. Martin-Pena R, Dominguez-Herrera J, Pachon J, McConnell MJ. Rapid detection of antibiotic resistance in Acinetobacter baumannii using quantitative real-time PCR. J Antimicrob Chemother 2013;68:1572-5.

\section{Yazıșma Adresi/Address for Correspondence} Dr. Özgen KÖSEOĞLU ESER

Hacettepe Üniversitesi Tıp Fakültesi, Tibbi Mikrobiyoloji Anabilim Dal, Ankara-Türkiye

E-posta: eser.ozgen@gmail.com 